\title{
MENGEVALUASI HUKUMAN KEBIRI DAN PENTINGNYA FATWA MAJELIS ULAMA INDONESIA
}

\author{
Moh. Rasyid
}

Dosen IAIN Kudus

\begin{abstract}
Children need protection and guidance from adult people to become a quality generation. Relationship between children and adult people in their surrounding community plays significant role in children development. However, in some case, adult people cause suffering for children such as in the case of child abuse or violence. Meanwhile, the regulation concerning child fails to provide protection for children. Due to the rise of crime against children, President Joko Widodo signed Perppu No 1/2016, later on became the Law no 17/2016, which threatened the actor of child abused to be emasculated. Human right activists and medical experts were opposing the law. Despite the debate between the proponents and the opponents of castration, including among Moslems, the Council of Indonesian Ulama (MUI) did not published fatwa concerning this matter. The most important thing is protecting children from being abused by empowering education and restorative justice.
\end{abstract}

Keywords: castration, consistency, punishment

\begin{abstract}
Abstrak
Anak sebagai individu memerlukan perlindungan dari pihak yang dewasa agar menjadi generasi yang berkualitas. Hubungan antara anak dengan lingkungannya yang dewasa pada tataran tertentu menghadapi fase krusial. Akan tetapi terkadang ada perilaku oknum orang dewasa yang memosisikan anak sebagai korban tindak kriminal (pemerkosaan, pencabulan, dsb). Di sisi lain, pemerintah berpandangan bahwa hukum yang digunakan menjerat pelaku kurang menimbulkan efek jera. Kondisi ini muncul inisiatif Presiden Jokowi menerbitkan Perppu Nomor 1 Tahun 2016 yang disahkan menjadi UU Nomor 17 Tahun 2016 bahwa orang dewasa yang menjadi pelaku tindak kriminal pada anak dapat diberi hukuman kebiri. Dari proses awalnya, lahirnya perppu mendapat penolakan dari pegiat hak anak dan ahli medis. Terbitnya perppu hingga menjadi UU, pemerintah tidak mengajukan permohonan diterbitkannya fatwa pada MUI. Hal ini berakibat kurang kokohnya landasan hukum (bagi muslim) tanpa adanya fatwa. Apa pun wujudnya, hal yang paling penting untuk disikapi agar anak tidak menjadi korban dan yang dewasa tidak menjadi pelaku kriminal adalah realisasi pendidikan kesehatan reproduksi dan seksual, selain merealisasikan keadilan restoratif pada anak.
\end{abstract}


Kata Kunci: kebiri, konsistensi, dan hukuman.

\section{Pendahuluan}

Perserikatan Bangsa-Bangsa (PBB) meluncurkan program Millenium Development Goals (MDGs) pada September 2000. Tujuannya menanggulangi kemiskinan dan kelaparan, mencapai pendidikan dasar untuk semua, mendorong kesetaraan jender dan pemberdayaan perempuan, menurunkan angka kematian anak, meningkatkan kesehatan ibu, memerangi HIV/Aids, malaria, dan penyakit menular lainnya pada warga dunia. MDGs berakhir pada 2016 yang dilanjutkan dengan program sustainable development goals (SDGs) yakni program pembangunan berkelanjutan di mana di dalamnya terdapat 17 tujuan, yakni pembangunan berkelanjutan hingga tahun 2030 dengan 169 target. Indonesia mendeklarasikan agenda pembangunan pasca 2015 pada 25 September 2015 di New York AS. Keberhasilan program MDGs di

\footnotetext{
${ }^{1}$ Sonny Harry B Harmadi. SDG dan Makna

Pembangunan. Kompas, Kamis 14 April 2016, h.6.
}

Indonesia berupa penurunan jumlah kematian balita dan peningkatan pendidikan dan kesetaraan jender. Di sisi lain, MDGs belum berhasil dalam hal penurunan angka kematian ibu melahirkan (359 kematian ibu per 100.000 kelahiran), akses air minum dan sanitasi layak di pedesaan, prevalensi malnutrisi pada balita, belum terkendalinya penyebaran kasus HIV/Aids, dan adanya ketimpangan pencapaian target antardaerah. SDGs menjadi komitmen 193 negara dengan tiga pilar utama. Pertama, pembangunan manusia mencakup kesehatan, pendidikan, dan kesetaraan jender. Kedua, pembangunan ekonomi sosial, seperti ketimpangan, kemiskinan, ketersediaan sarana dan prasarana lingkungan, dan pertumbuhan ekonomi. Ketiga, pembangunan lingkungan dengan menjaga ketersediaan sumber daya alam dan kualitas lingkungan. ${ }^{1}$ Di antara tujuan SDGs tersebut adalah 
kesehatan, pendidikan, dan kesetaraan jender yang perlu dikawal dan diantisipasi atas hal yang mengganggunya.

Gangguan harus diantisipasi sedari dini, di antaranya upaya Dirjen Imigrasi Kemenkumham RI Minggu, 9 Oktober 2016 mendeportasi warga Amerika berinisial JED Jr (44 tahun) tatkala tiba di Bandara SoekarnoHatta. JED termasuk dalam daftar tangkal imigrasi dan Convicted Child Sex Offender (CCSO) sebagai pelaku kejahatan seksual terhadap anak di Amerika. Data diterima Imigrasi melalui intelijen keimigrasian dan kerja sama antarnegara. JED dipulangkan ke negaranya pukul 06.45 Wib setelah mendarat di Bandara Soetta.Tindakan antisipasi dilakukan karena adanya kekhawatiran bahwa JED akan berbuat tidak benar dengan perilakunya terhadap anak Indonesia karena anak korban kekerasan dapat berlanjut menjadi pelaku jika traumanya tak tertangani dengan baik. Pelaku kekerasan muncul karena multifaktor, baik internal maupun eksternal. Faktor internal seperti kelainan genetik dan hormonal. Orang dengan hormon testosteron tinggi cenderung lebih agresif, faktor eksternal seperti paparan kekerasan di media massa dan budaya kekerasan. Padahal, jumlah anak di Indonesia Oktober 2016 berdasarkan data Deputi Perlindungan Perempuan dan Anak Kementerian Pemberdayaan Perempuan dan Perlindungan Anak, terdapat 87 juta jiwa anak mencakup 34 persen total penduduk sehingga perlu perlindungan ekstra.

Undang-Undang Nomor 35 Tahun 2014 perubahan atas UU Nomor 23 Tahun 2002 tentang Perlindungan Anak belum menjamin keamanan, kenyamanan, dan kesejahteraan bagi anak di Indonesia. Penanganan atas kekerasan pada anak masih bersifat reaktif dan belum menyasar pada pokok permasalahan. Kekerasan terhadap anak sudah mencapai tahap memprihatinkan, baik dalam jumlah kasus maupun kekejamannya. Dalam kondisi ini, mewacana perlunya merevisi UU Perlindungan Anak. Urgensi merevisinya diawali/diwacanakan oleh Menteri 
Pemberdayaan Perempuan dan Perlindungan Anak era Presiden SBY Linda Amalia Sari bahwa hukuman untuk pelaku kejahatan terhadap anak harus diperberat agar memberi efek jera kepada pelakunya. Sanksi hukuman paling lama 15 tahun, realitanya tak pernah ada pelaku dihukum 15 tahun. Untuk itu, UU Nomor 35 Tahun 2014 tentang Perlindungan Anak perlu direvisi. Hal ini dinyatakan menteri pada pembukaan Konferensi Polisi Wanita se-Asia di Semarang Senin, 21 April 2014. Usulan ini sangat beralasan karena korban yang diderita anak akibat ulah pihak lain yang merugikan anak bahkan ada pelaku yang secara fisik dan psikis dekat dengan anak.

Data Tahunan Komisi Nasional AntiKekerasan terhadap Perempuan (Komnas Perempuan) selama 12 tahun berturut-turut, pada 2001-2012 terdapat 35 perempuan yang menjadi korban kekerasan seksual setiap hari, tahun 2012 tercatat 4.336, pada 2013 menjadi 5.629 kasus. Hanya seperdelapan kasus kekerasan seksual yang dilaporkan para korban, korban lainnya tidak mau melaporkan atau tidak mau bersaksi sehingga kasusnya dianggap tidak ada. Dengan demikian, setiap tiga jam, terdapat dua perempuan di Indonesia yang mengalami kekerasan seksual. Jumlah kasus yang terjadi diperkirakan lebih banyak karena hanya seperdelapan yang melaporkan. Penyebabnya, korban takut, minimnya lembaga pelayanan, sedikitnya polwan tempat korban mengadu atau melapor, pemberian stigma (dari sekolah, keluarga, dan masyarakat), sulitnya mengakses korban untuk melapor, dan persoalan adat istiadat. ${ }^{2}$ Di sisi lain, perlu dirumuskan agar anak tetap jera tidak menjadi pelaku kriminal, sebagaimana dilaporkannya anak lelaki 12 tahun oleh sang ibu kandungnya, Kartinah 48 tahun ke Polres Kudus pada Rabu 19 November 2014 karena sang ibu tak mau menuruti keinginannya melayani sarapan, sang anak memukul ibu dengan hanger (gantungan baju) hingga berdarah pada bagian

\footnotetext{
${ }^{2}$ Kompas, 22 November 2014.
} 
bibirnya. Pelaku tidak ditahan karena di bawah umur (restorative justice) dan masih tinggal bersama ibunya di Desa Loram Wetan Kecamatan Jati, Kudus. Si anak pun minta jajan hingga Rp 20.000 per hari, pagi Rp 10.000, siang Rp 5.000, dan malam Rp 5.000. ${ }^{3}$

Berdasarkan pengaduan yang masuk dan pantauan di berbagai media massa oleh Komisi Nasional Perlindungan Anak (Komnas PA) sepanjang tahu 2014, jumlah kejahatan terhadap anak menurun dari 3.339 kasus pada 2013 menjadi 2.737 kasus pada 2014. Akan tetapi, menurut Ketua Umum Komnas Perlindungan Anak, Arist Merdeka Sirait, jumlah anak yang bertindak sebagai pelaku kejahatan naik 10 persen. Sebanyak 52 persen dari kasus kejahatan terhadap anak pada 2014 merupakan kejahatan seksual, 24 persen dari pelaku kejahatan merupakan anak yang berumur di bawah 14 tahun. Bentuk kejahatan yang dilakukan berupa perundungan, pencurian, pencabulan, dan

\footnotetext{
${ }^{3}$ Suara Muria, Suara Merdeka, 22 November 2014.
}

${ }^{4}$ Kompas, 31 Desember 2014. pemerkosaan. Hal itu memperumit penanganan kasus karena anak di bawah umur tidak dapat dipidanakan. $^{4}$ Data Komisi Perlindungan Anak Indonesia (KPAI) pada Januari 2011 hingga November 2015 ada 18.365 pengaduan terkait pelanggaran hak pada anak. Rinciannya, tahun 2014 ada 5.066 kasus, tahun 2015 ada 3.298 pengaduan dengan 941 kasus anak berhadapan dengan hukum (sebagai korban dan pelaku). Bentuknya pembunuhan, perampokan, pencurian, dan aborsi. Kekerasan seksual pada anak (pedofilia) lazimnya berantai, maksudnya sebagian pelaku semula adalah korban kekerasan seksual. Data KPAI, selama tahun 2010-2014 tercatat $\quad 21.869 .797 \quad$ kasus pelanggaran hak anak yang tersebar di 34 provinsi dan 179 kabupaten dan kota. Sebesar 42-58 persen dari total pelanggaran itu merupakan kejahatan seksual terhadap anak. Selebihnya merupakan kasus kekerasan fisik dan penelantaran anak. ${ }^{5}$

\footnotetext{
${ }^{5}$ Kompas, 3 November 2015.
} 
Sebagai upaya melindungi anak, pemerintah menyusun Peraturan Pemerintah Pengganti UU (Perppu) terkait sanksi tambahan bagi pelaku kekerasan seksual terhadap anak di tengah kekosongan hukum atas pemberian sanksi ekstra. Keberadaan kebiri (kastrasi) sebagai sanksi tambahan agar timbul efek jera dan takut bagi yang akan bertindak negatif terhadap anak. Alternatif hukuman tambahan tersebut antara lain suntikan cairan kimia yang bisa menekan produksi hormon libido (pengebirian saraf libido), bukan memutus organ seksual pelaku. Teknik pengebirian dapat dilakukan dengan suntik, mengoles, atau meminum obat. Bila diukur dari aspek efektifitas hukuman kebiri, belum mendapatkan jawaban karena belum dilakukan di Indonesia. Hukuman kebiri awalnya usulan dari Komnas Perlindungan Anak Indonesia (KPAI) tahun 2013 ketika mengkaji darurat kejahatan seksual pada/oleh anak dan parameter hukumnya tidak ada. Wacana yang digagas KPA adalah (1) maksimal hukuman seumur hidup atau minimal
20 tahun dengan tambahan pemberatan hukum yang pertama berupa kastrasi atau kebiri melalui suntik kimia. Hukuman yang kedua berupa sanksi sosial (social punishment) yang sesuai dengan penetapan presiden, (2) penetapan bahwa semua kejahatan pada anak dikategorikan kejahatan luar biasa (extraordinary crime). Efek jera bagi pelaku dan takut bagi calon pelaku merupakan tujuan utama hukuman. Akan tetapi, hal yang harus dipertimbangkan aspek filosofis, yuridis, dan sosiologis bagi anak yang terhukum.

Sidang Kabinet Terbatas (Ratas) di Istana Negara Jakarta 20 Oktober 2015 Presiden Jokowi memutuskan akan membuat Perppu. Dalam ratas, Presiden Jokowi menggarisbawahi tiga hal (1) perlu ada pendidikan pranikah yang memuat ajaran bagaimana orangtua memahami cara melindungi anak-anak mereka, (2) tingginya perceraian memungkinkan penelantaran anak, (3) munculnya kekerasan seksual terhadap anak dilakukan pemberatan hukuman pada pelaku, termasuk di dalamnya 
pengebirian saraf libido. Menurut

Kejagung H.M Prasetyo, kekerasan seksual pada anak dikategorikan sebagai kejahatan luar biasa. Hal yang disepakati dalam ratas, lanjut Prasetyo, hukuman berupa pengebirian sebagai langkah prevensi/pencegahan. Ketua Komisi Perlindungan Anak Indonesia (KPAI), Asrorun Ni'am Sholeh yang hadir dalam ratas mendukung hasil ratas. Perppu sedang dikoordinasikan antara Kejagung, Kemenkes, Kemenkumham, dan Polri. Kemensos dan Kementerian Pemberdayaan Perempuan dan Perlindungan Anak menyiapkan rancangan instruksi presiden (Inpres) tentang pengarusutamaan perlindungan anak dalam pembangunan. Pemberlakukan hukuman tambahan berupa kebiri tentu berdasarkan putusan pengadilan dan rekomendasi dokter. Dasar hukum penerbitan Perppu adalah Pasal 22 ayat (1) UUD 1945 disebutkan "dalam hal ihwal kegentingan yang memaksa, Presiden berhak menetapkan peraturan pemerintah pengganti UU” (Perppu). Begitu pula Pasal 1 (4) UU Nomor 12
Tahun 2011 tentang Pembentukan Peraturan Perundang-undangan: "Peraturan pemerintah Pengganti UU (Perppu) adalah Peraturan Perundang-undangan yang ditetapkan oleh Presiden dalam hal ihwal kegentingan yang memaksa".

\section{Pemicu Munculnya Perppu}

Ketua Majelis Hakim Pengadilan Negeri Curup, Bengkulu Heny Farida dengan hakim anggota Hendry Sumardi dan Fakhrudin Kamis 29 September 2016 menjatuhkan hukuman mati terhadap Zainal. Adapun hukuman 20 tahun dan denda Rp 2 miliar subsider 3 bulan penjara dijatuhkan kepada empat teman Zainal yang terlibat yakni Tomi Wijaya, Masbobi, Muhammad Suket, dan Faisol Eldo Syaisah. Adapun pelaku lainnya bernama MJF (13 tahun) dinyatakan masih di bawah umur (dinyatakan usia anak bila kurang dari 18 tahun) dijatuhi hukuman rehabilitasi dan pelatihan kerja di Lembaga Penyelenggara Kesejahteraan Sosial (LPKS) Marsudi Putra Jakarta Timur selama setahun. Saat membacakan amar putusan, Ketua Majelis Hakim Heny 
Farida sempat meneteskan air mata, sehingga sidang pun terhenti beberapa menit dan ruang sidang seketika hening. Setelah menghapuskan air mata, Heny melanjutkan sidang dan memvonis mati terdakwa. ${ }^{6}$ Sebanyak 12 terdakwa kasus pembunuhan dan pemerkosaan tersebut divonis hukuman penjara selama 10 tahun dengan pelatihan kerja selama enam bulan. Putusan ini dibacakan Majelis Hakim yang diketuai Heni Farida dalam persidangan di PN Curup, Kabupaten Rejanglebong, Bengkulu, Selasa 10 Mei 2016. Hukuman tersebut sesuai tuntutan jaksa. Zainal dkk memerkosa dan membunuh Yuyun usia 14 tahun pada 2 April 2016 di kebun karet kawasan Lembak, Kabupaten Rejang Lebong, Bengkulu dan jenazah ditemukan warga di semak-semak pada 4 April 2014 dalam kondisi jasad terikat. Hakim menyatakan, Zainal dkk secara sah dan meyakinkan kelima terdakwa terbukti melakukan kekerasan dan memaksa anak melakukan persetubuhan dengannya dan orang lain serta melakukan kekerasan sehingga menyebabkan kematian korban. Pelaku dijerat Pasal 340 KUHP dan Pasal 80 ayat (3) dan Pasal 81 ayat (1) juncto Pasal 76 huruf D UU Nomor 35 Tahun 2014 tentang Perlindungan Anak pada persidangan tertutup. Jaksa menuntut kelima terdakwa berbeda-beda. Untuk Zainal dituntut hukuman mati karena sebagai otak, pelaku utama, dan eksekutor, sedangkan empat pelaku lainnya dituntut hukuman 20 tahun penjara. Kelima terdakwa merupakan pelaku dewasa pembunuhan dan perkosaan siswa kelas VIII SMP di Kecamatan Padang Ulak Tanding, Kabupaten Rejanglebong, Bengkulu, 7 pelaku masih di bawah umur telah terlebih dahulu divonis dengan hukuman penjara 10 tahun.

Kronologi pemerkosaan dan pembunuhan tersebut bermula saat 14 tersangka pada Sabtu, 2 April 2016 sekitar pukul 11.31 Wib berkumpul di rumah tersangka berinisial DE yang meminum tuak. Pada pukul 12.31 Wib dalam keadaan mabuk, ke-14

${ }^{6}$ Okezone. Com, 29 September 2016. 
tersangka keluar dari rumah dan duduk di tepi jalan perkebunan karet di Desa Kasie Kasubun, Kecamatan Padang Ulak Tanding (PUT). Sekitar pukul 13.31 Wib, pelaku melihat korban pulang sendirian dengan membawa alas meja dan bendera merah putih akan dicuci untuk persiapan upacara bendera hari Senin. Jarak antara rumah orangtua korban dengan sekolah korban kurang lebih 1 km dan melintasi jalan kebun karet. Para pelaku langsung mencegat dan menyekap Yuyun. Kepala Yuyun dipukul menggunakan kayu, kaki dan tangannya diikat, dan lehernya dicekik, kemudian para pelaku secara bergiliran memerkosa korban. Akhirnya korban dibuang disemaksemak. ${ }^{7}$ Sebelum vonis dijatuhkan, polisi menggelar rekonstruksi kasus terbunuhnya gadis di Rejanglebong, Bengkulu, dengan 63 adegan. Rekonstruksi digelar di halaman Mapolres Rejang Lebong Kamis, 2 Juni 2016. Ada 12 pelaku, 7 di antaranya berusia di bawah umur dan lima di antaranya berstatus pelajar dan sisanya anak putus sekolah berusia 16 tahun dan maksimal usia pelaku adalah 23 tahun. Dalam hal lain, korban memiliki saudara kandung/kembar, oleh Mensos Khofifah Indar Parawansa akan difasilitasi pendidikan di Malang Jawa Timur.

Setelah terbongkarnya pemerkosaan dan pembunuhan tersebut, Menteri Pemberdayaan Perempuan dan Perlindungan Anak Yohana Yambise berpikir untuk meninjau UU Perlindungan Anak. Wacana ini muncul setelah terjadinya kasus tersebut. Hal yang perlu kewaspadaan, sebelum pelaku memerkosa, mereka menonton adegan porno dan meminum minuman keras. Dengan kasus tersebut yang didahului ragam kasus serupa maka upaya mewujudkan terbitnya Perppu kian kencang.

\section{Mendefinisikan Pemerkosaan}

Menurut dosen psikologi klinik Fakultas Psikologi UI, Nathanel Sumampouw, pemerkosaan merupakan kejahatan manusia paling brutal sejak zaman purba. Pemerkosaan tak hanya demi

\footnotetext{
7 Okezonenews.Com, 4 Mei 2016.
} 
menunjukkan dominasi jender dan kelas, tetapi juga alat politik atas nama kebencian dan penghilangan etnis tertentu. Pandangan kuno yang bias jender menganggap pemerkosaan sebagai kejahatan atas kepemilikan, merampas keperawanan seseorang yang dianggap milik orangtua. Pemerkosaan dinilai menjadi upaya mempertontonkan kekuasaan lelaki yang dalam pandangan budaya dianggap superior. Menurut psikiater dan dosen Fakultas Kedokteran Unair Surabaya, Nalini Muhdi, pemerkosa bukan ingin mencari kepuasan seksual. Pemerkosa ialah orang yang butuh menunjukkan dominasi atas ketidakberdayaan orang lain melalui tindakan seksual, seksualitas sebagai alat. Pemerkosa biasanya memiliki sindrom inferioritas amat kuat dan citra diri (self esteem) buruk. Dengan memerkosa, mereka ingin meninggalkan rasa percaya diri. Jadi, pemerkosaan tak hanya soal ketidakmampuan menahan nafsu, tetapi ada yang salah dalam jiwa pelaku. Pemerkosaan tak terkait dengan seks bebas, legalitas prostitusi, status perkawinan, cara perempuan berperilaku atau berbusana. Buktinya, di negara yang membebaskan urusan seksual warganya atau mengatur ketat busana perempuan, tingkat pemerkosaannya tetap tinggi. Inferioritas pemerkosa dipicu banyak hal, mulai dari pola asuh yang membuatnya kerdil, tak berdaya mengatasi masalah atau kesulitan hidup, budaya hingga trauma masa kecil. Berbagai faktor biopsikososial membuat profil psikologi pemerkosa amat bervariasi. Pemicu pemerkosaan akan terjadi jika seseorang memiliki berbagai faktor risiko biopsikososial menemukan pencetus, misalnya tontonan pornografi, minuman beralkohol, hadirnya korban atau lemahnya kontrol sosial. Alkohol dan pornografi bukan penyebab pemerkosaan, tetapi pencetus. Saat mabuk, pertimbangan seseorang turun. Akibatnya, saat ada calon korban, mereka mudah melampiaskan superioritasnya, tak 
peduli korban itu cantik, memiliki kesempurnaan fisik atau tidak. ${ }^{8}$

Tindak pemerkosaan adalah hubungan seksual yang dilakukan secara paksa dan merugikan pihak korban. Adapun pemerkosaan merupakan suatu usaha melampiaskan nafsu seksual oleh seseorang terhadap korban dengan cara yang tidak etis menurut moral dan/atau hukum yang berlaku. Pemerkosaan terhadap anak adalah salah satu bentuk dari tindak kekerasan kejahatan yang meresahkan. Dampaknya bukan hanya fisik tapi psikis yang akan dibawa dalam pikiran korban hingga meninggal dunia. Tindak pemerkosaan adalah puncak dari tindak pelecehan seksual yang paling mengerikan. Dampak secara fisik ada kalanya berupa vaginismus, yakni otot dinding vagina selalu berkontraksi atau menguncup saat melakukan hubungan kelamin. Minimal korban akan mengalami dispareunia yaitu rasa nyeri atau sakit yang dirasakan sebagai penderitaan

\footnotetext{
${ }^{8}$ Kompas, 24 Mei 2016.
}

bila melakukan hubungan seksual. Dampak psikis berupa merasa tidak nyaman dan tak aman, menurunnya harga diri dan martabatnya sehingga tumbuh dengan yang terluka. Menurut Wahid dan Irfan, perkosaan menjadi salah satu tolok ukur pelanggaran HAM yang cukup parah terhadap perempuan. Aksi yang diperbuat pelaku merupakan bukti kesewenang-wenangan dan kekejian yang bertentangan dengan watak diri manusia yang seharusnya menghormati hak sesamanya. ${ }^{9}$ Trauma penderitaan pasca-perkosaan pada perempuan bila di atas 6 tahun berupa gelisah, mimpi buruk, dan perilaku seks menyimpang. Bila berusia 7-12 tahun berupa ketakutan, agresif, neurotik ('bermain' dengan boneka), masturbasi berlebihan, meminta pertolongan orang lain untuk rangsangan seksual, memasukkan benda ke genital atau anal. Dampak lainnya, gangguan mental atau mengeluh kondisi fisiknya. Beragam akibat tergantung usia korban dan penderitaan yang

\footnotetext{
${ }^{9}$ Abdul Wahid dan Muhammad Irfan. Perlindungan terhadap Korban Kekerasan Seksual, Bandung, (Refika Aditama, 2001), h. 65.
} 
dialami. ${ }^{10}$ Pemerkosa dalam

perspektif psikologi sosial berperilaku agresif. Agresif menurut Faturochman adalah perilaku emosional, kesengajaan, akibat multifaktor, dan adanya kecederungan internal berupa insting yang munculnya tidak setiap saat. ${ }^{11}$

Untuk mencegah agar tindak kekerasan seksual pada anak tidak kian marak, wacana publik memberi hukuman disuntik hormon yang dapat menghilangkan libido nafsu seksualnya dengan kebiri. Meski ancaman tambahan hukuman kebiri sulit berjalan efektif. Bila ditimbang penderitaan yang ditanggung korban seumur hidupnya, hukuman kebiri jauh lebih ringan atau setimpal dengan penderitaan korban. Hal yang lebih penting adalah menjamin proses persidangan untuk membuktikan terjadi atau tidaknya kasus perkosaan tidak menjadi bentuk pemerkosaan baru yang justru merugikan korban. Sebagaimana pemerkosaan yang dicoba diselesaikan secara hukum,

10 Marzuki Umar Sa'abah. Perilaku Seks Menyimpang dan Seksualitas Kontemporer, Yogyakarta, (UII Press, 2001), h. 77.

${ }^{11}$ Faturochman. Pengantar Psikologi Sosial, Yogyakarta, (Pustaka, 2006), h. 82. kadang-kadang menarik di tengahtengah, karena pihak keluarga mencabut pengaduannya dan lebih memilih memendam penderitaannya karena tidak menginginkan anaknya trauma akibat proses pengadilan yang memaksa mereka mengingat kembali aib yang telah dialami. Mengesahkan hukuman kebiri bagi pelaku tindak kejahatan seksual terhadap anak, sebagai suntikan dukungan moral bagi anak yang jadi korban tindak pemerkosaan memanng dibutuhkan. Tetapi, membuktikan kesalahan pelaku dalam persidangan menambah beban penderitaan baru bagi korban. ${ }^{12}$ Pro - Kontra Hukuman Kebiri

Dari asal-usulnya, hukuman kebiri berasal pada era 8.000-9000 tahun lalu di timur Mediterania. Budak di Mesir dikebiri sejak tahun 2.600 SM agar lebih rajin dan patuh pada majikan. Masa berikutnya, kebiri ditemukan pada budaya Yunani, Persia, hingga Tiongkok. Dalam perkembangannya, kebiri dilakukan untuk mendapat suara soprano pada

\footnotetext{
12 Bagong Suyanto. Ancaman Kebiri bagi Pemerkosa Anak. Kompas, 3 November 2015, h.7.
} 
anak lelaki, mencegah perbuatan tak bermoral dalam sejumlah agama dan keyakinan, dan mengurangi jumlah penduduk yang mengalami gangguan fisik dan mental. Pada abad ke-20 kebiri dijadikan sebagai hukuman bagi penjahat seksual anak di sejumlah negara. Pelaksanaan kebiri dilakukan pada hewan ternak agar jumlah hewan betina lebih banyak dibanding pejantan. Menyikapi terjadinya tindak kekerasan seksual pada anak, orangtua memberikan perhatian ekstra agar tidak menjadi korban atau pelaku. Pemberian hukuman tidak hanya menjerakan pelaku, tapi menghargai etika, hak asasi manusia, dan tak bersifat balas dendam. ${ }^{13}$

Kebiri atau katrasi adalah tindakan medis berupa bedah yang menggunakan bahan kimia bertujuan untuk menghilangkan fungsi testis pada lelaki atau fungsi ovarium pada perempuan. Pro-kontra terhadap wacana pemberlakuan sanksi kebiri atas perlakuan kejahatan seksual terhadap anak direspon pemerintah.

\footnotetext{
${ }^{13}$ M. Zaid Wahyudi. Efektivitas Kebiri Masih Dipersoalkan. Kompas, 23 Oktober 2015, h.14.
}

Awalnya,

Kementerian

Pemberdayaan Perempuan dan

Perlindungan Anak membuka diri untuk menerima masukan dari berbagai kalangan sambil terus mengkaji beberapa alternatif hukuman lain yang lebih efektif. Bagi yang kontra berpendapat bahwa kebiri tidak menyelesaikan masalah, hukuman itu belum menjadi solusi ampuh dan belum terbukti secara ilmiah efektif menurunkan kekerasan pada anak. Ada yang berpendapat, hukuman tambahan berupa hukuman mati, hukuman seumur hidup, hukuman sanksi sosial, meski dalam UU Nomor 35 Tahun 2014 tentang Perlindungan Anak hukuman maksimal hingga 20 tahun. Namun penegak hukum belum pernah melakukan hukuman maksimal. Negara yang memberlakukan hukuman kebiri yakni Jerman sejak tahun 1902, Korsel sejak 2012, Rusia, Inggris, dan beberapa negara bagian di Amerika. Bentuknya ragam, ada yang bedah saraf libido dan kebiri kimiawi lewat penyuntikan. 
Kekejaman yang diderita anak dalam bentuk pemerkosaan dan pembunuhan terus terjadi. Hal ini diderita Yuyun (14 tahun) warga Desa Kasie Kasubun, Kecamatan Padang Ulak, Kabupaten Rejang Lebong, Bengkulu yang memantik pemberitaan. Yuyun diperkosa oleh 14 pria pemabuk, dua pemerkosa masih tergolong anak, hingga tewas. Pemerkosa dapat dijerat Pasal $76 \mathrm{C}$ jo Pasal 80 ayat (3) dan Pasal 76 D jo Pasal 81 ayat (1) UU Perlindungan Anak. Masing-masing ancaman pidanya 15 tahun penjara dengan pidana denda Rp 3 miliar untuk Pasal $76 \mathrm{C}$ dan denda $\mathrm{Rp} 5$ miliar untuk Pasal 76 D. Dengan fakta tersebut yang didahului fakta lainnya, Presiden Jokowi Selasa 10 Mei 2016 seusai memimpin sidang kabinet memandang kekerasan terhadap anak yang terus terjadi sebagai kejahatan luar biasa sehingga harus segera diakhiri dengan cara luar biasa pula tanpa semata-mata mengacu pada UU. Pelaku akan diberi hukuman secara akumulatif. Pemerintah (saat itu) masih memproses rancangan peraturan pemerintah pengganti UU
(Perppu) mengenai hukuman tambahan kepada pelaku kejahatan seksual terhadap anak agar ada sebuah keputusan yang betul-betul memberikan efek jera kepada pelaku serta bisa menghilangkan keinginan calon pelaku lainnya. Presiden memerintahkan pada Menteri Koordinator Pembangunan Manusia dan Kebudayaan Puan Maharani melakukan koordinasi lintas kementerian dengan Polri untuk menangani kasus-kasus kejahatan terhadap anak secara komprehensif. Jaksa Agung Prasetyo menyatakan, pihaknya menganggap pernyataan presiden sebagai instruksi dalam penegakan hukum secara luar biasa kepada pelaku kekerasan seksual terhadap anak. Jajarannya harus segera memelajari semua aturan hukum yang ada untuk menyiapkan tuntutan seberat-beratnya kepada pelaku kekerasan seksual terhadap anak dengan tuntutan berdasarkan UU Nomor 35 Tahun 2014 tentang Perlindungan Anak dan KUH Pidana. Rapat yang diselenggarakan Kementerian Koordinator Pembangunan Manusia dan 
Kebudayaan, Selasa 10 Mei 2016 intinya, hukuman bagi pelaku tindak kekerasan seksual terhadap anak akan diperberat menjadi seumur hidup dan menjadi hukuman mati apabila korban meninggal. Pemerintah akan menyiapkan peraturan perundangan untuk merevisi UU Nomor 23 Tahun 2002 tentang Perlindungan Anak, untuk menambahkan hukuman tersebut. Menurut Menteri Hukum dan HAM Yasonna H Laoly, penambahan hukuman akan dilakukan dengan merevisi UU Perlindungan Anak Pasal 81 tentang ketentuan pidana maksimal 15 tahun bagi pelaku kekerasan, ancaman kekerasan, memaksa anak melakukan persetubuhan dengannya atau dengan orang lain. ${ }^{14}$

Dengan dikategorikannya kekerasan seksual sebagai kejahatan luar biasa, Presiden Jokowi memutuskan akan menerbitkan peraturan pemerintah pengganti UU (Perppu) untuk memperberat hukuman bagi pelaku (maksimal 20 tahun), hukuman tambahan berupa kebiri, pemasangan gelang elektronik (cip) agar terdeteksi pergerakannya, dan sanksi sosial berupa publikasi identitas pelaku pada publik. Presiden Jokowi di Istana Merdeka, Jakarta, Rabu 25 Mei 2016 menerbitkan Perppu Nomor 1 Tahun 2016 tentang Perlindungan Anak. Hal ini sebagai upaya mengatasi kegentingan akibat maraknya kekerasan seksual terhadap anak. Menurut Presiden, kejahatan ini mengancam dan membahayakan jiwa anak, merusak kehidupan pribadi dan pertumbuhan anak dan masyarakat. Perppu diharapkan memberikan efek jera terhadap para pelaku. Penambahan hukuman pada pasalpasal tersebut juga diharapkan memberikan ruang pada hakim memutuskan hukuman kepada pelaku seberat-beratnya. Dalam Pasal 81 ayat 1 dan 2 Perppu Nomor 1 Tahun 2016, mereka yang dengan tipu muslihat, membohongi, membujuk, dan melakukan ancaman dan kekerasan memaksa anak bersetubuh atau sesuai Pasal 76 D UU Nomor 35 Tahun 2014, pelaku dipidana penjara 5 tahun dan 15 tahun dan denda Rp 5 miliar. Ayat 3 menyebutkan, jika hal

\footnotetext{
${ }^{14}$ Kompas, 11 Mei 2016.
} 
itu dilakukan oleh orangtua, wali, orang yang memiliki hubungan keluarga, pengasuh anak, pendidik, aparat yang menangani perlindungan anak atau dilakukan lebih dari satu orang atau bersama-sama, pidananya ditambah sepertiga dari ancaman pidana, seperti dituangkan dalam ayat $1 .^{15}$

Susanto, Wakil Ketua Komisi Perlindungan Anak Indonesia (KPAI) menyatakan, kejahatan seksual terhadap anak merupakan kasus serius. Kasusnya terus meningkat, baik kuantitatif maupun kualitatif, modusnya pun kian tak berperikemanusiaan, yakni mulai dari bujuk rayu, paksaan, perkosaan, pembunuhan bahkan mutilasi. Anak merupakan kelompok rentan, sekitar 75 persen korban kekerasan seksual adalah usia anak (di bawah usia 18 tahun). Komitmen Presiden Jokowi yang memasukkan kejahatan seksual sebagai kejahatan luar biasa layak diapresiasi. Merebaknya kejahatan seksual terhadap anak bukan sematamata dipengaruhi minimnya pidana terhadap kejahatan seksual, juga rentannya ketahanan keluarga yang berujung pada kerentanan anak menjadi korban dan pelaku, mudahnya akses terhadap pornografi yang menginspirasi seseorang melakukan kejahatan seksual. Penerbitan Perppu merupakan subsistem reformasi perlindungan anak yang fundamental dan menandai telah terjadi perubahan paradigma besar dalam penyelenggaraan perlindungan anak. Pertama, perlindungan anak menjadi prioritas isu yang mendesak ditangani, kompleksitas masalah yang ada dapat dikategorikan masuk stadium 'genting' sehingga perlu diambil langkah segera. Kedua, norma hukum yang ada belum memberikan efek jera. Untuk menekan tingginya kasus kejahatan seksual anak perlu pemberatan hukuman bagi pelaku. Ketiga, ketertarikan kepada lawan jenis melakukan hal natural, karena setiap manusia memiliki 'insting seksual' sebagaimana insting mencari makan dan juga rasa lapar. Insting ini dalam dunia sains disebut 'libido'. Namun hasrat seksual yang liar dan

\footnotetext{
${ }^{15}$ Kompas, 26 Mei 2016.
} 
tak terkendali dan dilampiaskan kepada anak merupakan bentuk kejahatan dan tak bisa dibiarkan. Keempat, hasrat seksual tak boleh dihilangkan, karena bersifat given dan bagian dari HAM. Sikap sebagian pegiat HAM yang kurang sependapat dengan Perppu perlu dihormati, tetapi semangat Presiden juga perlu diapresiasi. $^{16}$

Pihak-pihak yang menolak Perppu antara lain, Sahabat Anak dan Perempuan Indonesia, Lembaga Bantuan Hukum Indonesia (LBHI), Asosiasi Perempuan Indonesia untuk Keadilan, Institute for Criminal Justice Reform Erasmus mereka mewakili 99 organisasi menolak Perppu Nomor 1 Tahun 2016 Minggu, 29 Mei 2016 di Jakarta. ${ }^{17}$ Menurut Konsultan Psikiater Unair Surabaya, Nalini Muhdi, ada dua jenis kebiri, yakni (1) kebiri fisik melalui pembedahan untuk mengangkat dua testis atau buah zakar (tempat lelaki memproduksi sperma dan hormon testosteron). Bila testis tak lagi memproduksi hormon

\footnotetext{
16 Susanto. Presiden Ramah Anak. Kompas, 31 Mei 2016, h. 7.
}

testosteron maka laki-laki tak akan bergairah seks dan (2) kebiri kimiawi, yakni menyuntikkan zat kimia tertentu yang umumnya obat antiandrogen atau hormon 'antitestosteron'. Keduanya berfungsi menekan produksi hormon testosteron untuk mengurangi dorongan seksual. Testosteron dihasilkan kelenjar anak ginjal, tapi jumlahnya amat sedikit. Kebiri kimiawi dianggap lebih beradab dan sesuai perkembangan sains dan teknologi dibanding kebiri fisik karena memberi efek sama tanpa membuang testis. Ada 10-20 persen orang yang dikebiri masih bisa beraktivitas seksual, tak berbentuk penetrasi tapi seks oral dan manipulasi manual dengan tangan. Motivasi pelaku kejahatan seksual pada anak tak hanya soal seks. Tiap kejahatan seks ada faktor agresivitas pelaku. Kebiri hanya menekan dorongan seksual pelaku, tapi tidak bisa mengatasi agresivitasnya. Bahkan, tertekannya dorongan seksual bisa meningkatkan

\footnotetext{
${ }^{17}$ Kompas, 30 Mei 2016.
} 
agresivitas pelaku sehingga bisa melakukan berbagai tindakan kekerasan lain. Jenis kekerasan yang muncul sangat beragam, yakni kekerasan fisik, verbal, dan seksual. ${ }^{18}$ Menurut Mohamad, kebiri dengan zat nekrotikans efeknya permanen seperti operasi membuang testis, seumur hidup lelaki tak lagu mempunyai libido seks. Akan tetapi, bila dengan obat penekan produksi testosteron akan bersifat semipermanen selama beberapa bulan saja, sesudah itu harus disuntik ulang. Pola ini juga digunakan bagi lelaki yang seksnya terlalu berlebihan dan untuk mengobati kanker prostat. Wacana kebiri kimiawi bagi pelaku pemerkosaan kambuhan menimbulkan kontroversi pelanggaran HAM karena kehilangan kebebasan, (2) sampai kapan pemberian obat. Kebiri harus dilakukan dokter tapi dokter akan melanggar kode etik kedokteran. Dokter harus menolak bila bagian dari penyiksaan (torture), tapi tak menolak bila bagian dari terapi libido

\footnotetext{
${ }^{18}$ Kompas, 23 Oktober 2015.
}

berlebihan. ${ }^{19}$ Menurut info yang penulis peroleh dari dokter ahli bedah bahwa tidak diperbolehkan kebiri fisik, tapi bila kebiri kimia perlu biaya 46 juta per bulan per orang. Dengan demikian, sang ahli bedah lebih setuju bila hukuman kurungan 30 tahun.

Menurut Zaidan, hukuman dalam bentuk pengebirian dalam Perppu Nomor 1 Tahun 2016 dapat dinilai telah mengembalikan semangat untuk membalas dendam terhadap pelaku tindak pidana. Hukum maupun hukuman bukan semata-mata untuk pembalasan atau perbaikan (resosialisasi) tapi dimaksudkan untuk memulihkan keseimbangan yang terganggu akibat tindak pidana dengan mewajibkan kepada si pelanggar untuk mengganti kerugian terhadap korban dalam hal tindak pidana itu menimbulkan kerugian material. Dalam konteks Perppu di atas, sepanjang berkaitan dengan hukuman kastrasi telah menghidupkan kembali teori pidana klasik sebagai sarana pembalasan. Meskipun hukuman kastrasi

19 Mohamad, Kartono. Pemerkosa Dikebiri. Kompas, 18 Mei 2016, h. 6. 
dipandang sebagai upaya terakhir di mana penerapannya harus selektif, disebabkan karena pengulangan atau menimbulkan korban yang meluas. Hal itu tetap menimbulkan akibat yang tidak humanis. PBB sejak 1984 mengesahkan konvensi yang menentang penyiksaan, tindakan lain yang kejam, tidak manusiawi atau tindakan/hukuman yang merendahkan (Convention Against Torture and Other Cruel, Inhuman or Degrading Treatment or Punishment). Indonesia telah meratifikasinya dengan UU Nomor 5 Tahun 1998. Konsekuensinya, caracara yang tak manusiawi dalam penegakan hukum, baik yang menyangkut proses penyidikan sampai peradilan harus dihindarkan. ${ }^{20}$ Belum ada data yang dapat dijadikan dasar jenis hukuman yang lebih berefek jera dan meniadakan kejahatan seksual, termasuk bila dengan kebiri. Tidak mungkin hanya dengan sekali pemberian obat (dikebiri) dorongan seksual langsung hilang dan tak mampu melakukan

\footnotetext{
${ }^{20}$ M. Ali Zaidan. Hukuman yang Merendahkan. Kompas, 31 Mei
} 2016, h. 7 . hubungan seksual. Ditekannya hormon testosteron sehingga rendah berakibat terjadi penurunan dorongan seksual. Tapi dorongan seksual tak hanya dipengaruhi oleh hormon testosteron tapi juga oleh pengalaman seksual sebelumnya; kondisi kesehatan secara umum, dan faktor psikologis terkait fungsi seksual. Pengalaman seks melekat di pusat seks yang ada di otak. Jadi meskipun mendapat obat anti testosteron, belum tentu keinginan melakukan hubungan seksual lenyap sama sekali. Penurunan hormon testosteron juga akan mengganggu fungsi organ tubuh yang lain, seperti otot yang mengecil, tulang mengeropos, sel darah merah berkurang, dan fungsi kognitif (berpikir) terganggu. Beberapa kemungkinan tersebut perlu dipikirkan sebelum melakukan hukuman kebiri. ${ }^{21}$

Ketua Komnas HAM (saat itu) Imdadun Rahmat menyayangkan pasal tentang kebiri kimiawi ada di Perppu yang dianggapnya menyalahi koridor HAM karena potensinya

\footnotetext{
21 Wimpie Pangkahila. Kebiri Kimia bagi Penjahat Seksual. Kompas, 13 Mei 2016, h. 6.
} 
berdampak jangka panjang bagi fisik atau psikis seseorang dan berpotensi merusak tubuh. Menurut Komisi Nasional Antikekerasan terhadap Perempuan Mariana Amiruddin, Perppu dinilai tak memberikan solusi karena kekerasan seksual berdasarkan riset bukan semata-mata reaksi libido, melainkan mengandung unsur kemarahan terhadap situasi sosial, ekonomi, atau politik pelaku. Menurut psikolog anak Seto Mulyadi, kekerasan seksual merupakan masalah kejiwaan, bukan soal libido. ${ }^{22}$ Menurut dosen filsafat UI, Rocky Gerung bahwa upaya menghapus kekerasan seksual tidak tepat jika hanya menonjolkan pendekatan hukum. Hal itu lebih arif jika didekati dari berbagai sisi, termasuk budaya. Kentalnya pendekatan hukum mencerminkan kebijakan dari rezim yang panik, reaktif, tanpa refleksi, dan hukum sebagai instrumen reaktif. Yang perlu diubah adalah kultur patriarki. Kultur itu bermukim di agama, tradisi lokal, bahkan struktur politik. Kebiri merupakan praktik kebengisan yang

\footnotetext{
${ }^{22}$ Kompas, 26 Mei 2016.
}

lahir dari tradisi patriarki. Rezim yang panik selalu bereaksi tanpa refleksi. Akibatnya, kekerasan tak berkurang dan bertambah tingkat kekejiannya. Menurut guru besar sosiologi UI, Thamrin Amal Tomagola menilai, pemerkosaan terjadi karena relasi kekuasaan yang timpang antara pria dan perempuan. Cara pandang ini sejak lama mengakar di masyarakat. Saatnya membenahi relasi antarpihak di masyarakat. Dalam hal ini, pendidikan di tingkat keluarga dan komunitas harus mendorong penyadaran kesetaraan jender di mana kaum pria dan perempuan tidak saling mendominasi. Penambahan hukuman kebiri atau mati tak akan efektif mengatasi persoalan. Itu tindakan refresif yang mengedepankan kekuasaan. ${ }^{23}$

Satu di antara tiga rekomendasi rapat terbatas Presiden tanggal 20 Oktober 2015 sehingga mewacanakan hukuman kebiri. Kebiri bertujuan mengebiri saraf libido. Menurut Dokter spesialis saraf RS Siloam, Lippo, Karawaci, Tangerang, Rocksy Fransisca Vidiaty Situmeang, istilah

${ }^{23}$ Kompas, 25 Mei 2016. 
bedah saraf libido tak dikenal dalam dunia medis. Libido (nafsu birahi) pendorong hasrat seksual berpusat di bagian otak disebut amigdala. Artinya, jika ingin menekan libido, otak harus dibedah yang prosesnya rumit karena posisi amigdala tersembunyi di atas batang otak. Amigdala menjadi pusat sejumlah fungsi lain, termasuk emosi. Pembedahan otak sangat beresiko sehingga sebaiknya tidak dilakukan. Kebiri juga mengubah wujud pria, mulai dari membesarnya payudara, suara menjadi mirip perempuan, dan hilangnya bulu-bulu tanda kelamin sekunder pria. ${ }^{24}$

Hukuman kebiri dari aspek etika dianggap tidak tepat. Dalihnya, hak reproduksi dan regenerasi individu harus dihormati. Dampak kebiri secara medis antara lain meningkatkan kecemasan, stres, depresi, dan frustasi; mudah lelah; bulu badan berkurang; memperbesar kelenjar payudara pada pria; mengurangi massa otot; meningkatkan berat badan, menaikkan resiko penyakit jantung dan pembuluh darah; mengurangi kerapatan tulang dan meningkatkan resiko osteoporosis; hipertensi; migrain; meningkatkan kadar gula darah; memperkecil ukuran testis; tak mampu ereksi; dan mengurangi jumlah sel sperma. Aspek etika kebiri tidak tepat karena hak reproduksi dan regenerasi individu harus dihormati. Aspek medis adalah aspek etika, sedangkan dokter era modern melarang/dilarang melakukan kebiri. Teknik kebiri secara medis yakni diambil biji dzakarnya, dipotong syarafnya, dan disuntik untuk mematikan sel pembuat hormon. Menurut Irawaty, upaya yang lebih berorientasi pada penghukuman seharusnya bukan jadi pilihan utama upaya melawan kekerasan seksual. Apalagi jika pilihannya hukuman kebiri yang melulu berorientasi 'biologis', padahal persoalan kekerasan seksual memiliki akar yang kompleks, mulai dari cara berpikir, akses informasi tentang seksualitas yang minim, hingga lemahnya sistem dan kelembagaan yang terintegratif penghapusan kekerasan seksual,

\footnotetext{
${ }^{24}$ Kompas, 23 Oktober 2015.
} 
termasuk lemahnya partisipasi masyarakat dalam perang melawan kekerasan seksual. Semua upaya ini sangat penting, tetapi butuh waktu panjang untuk bisa menjadi 'solusi' bagi persoalan kekerasan seksual ini. Yang diperlukan upaya lebih praktis dan cepat penanganan situasi darurat kekerasan seksual dengan upaya jangka panjang yang berkesinambungan dan memilik efek terbangunnya perubahan cara berpikir dan cara pandang. Upaya yang memungkinkan diwujudkan adalah membangun sistem pengawasan terpadu dan menyeluruh di berbagai unit sosial yang dimiliki, seperti RT, RW, tempat ibadah, sekolah, dan tempat publik seperti terminal, stasiun dan bandara. Para predator terus diawasi publik mereka membuat berpikir ulang sebelum bertindak. ${ }^{25}$

Menurut Irwanto (Guru Besar Fakultas Psikologi Universitas Atmajaya Jakarta) bila membuat Perppu atau UU yang memberikan hukuman terberat, tetapi tak dapat dilaksanakan dengan baik karena

\footnotetext{
${ }^{25}$ Diah Irawaty. Sistem Pengawasan Terpadu Kekerasan Seksual. Kompas, 7 Juni 2016, h. 6.
}

kultur, kurang siapnya sumber daya manusia atau tidak adanya mekanisme yang memadai karena kurangnya investasi, lemahnya partisipasi masyarakat, dll. maka bisa menjadi bumerang. Mengambil ilustrasi, seperti binatang yang lemah, ia dapat mengubah penampilannya sedemikian rupa berharap agar predatornya takut. Ketika tujuan menakut-nakuti tak tercapai, yang terjadi adalah masyarakat telah terlanjur merasa aman karena anggapan hukum yang menakutkan tentu berhasil. Ketika kejahatan serius masih terjadi, hukum di Indonesia kehilangan kredibilitas. Persoalan kekerasan seksual terhadap perempuan dan anak bukan semata persoalan lemahnya produk hukum. Perlindungan anak memerlukan landasan hukum yang tepat, kuat, dan implementatif. Keberhasilan melindungi anak membutuhkan juga masyarakat yang peduli, berani melapor, berani mengambil tindakan menolong, mau bekerja sama dan mempunyai informasi yang baik 
untuk melindungi anak. Ketika hanya hukum yang menjadi perhatian publik, investasi dan upaya untuk memperbaiki community vigilance (kesadaran dan kewaspadaan komunitas), membangun keterampilan melapor dan menolong, melakukan berbagai tindakan pencegahan (termasuk melatih anak untuk waspada dan menolong dirinya) tidak akan terjadi. Dengan demikian, upaya perlindungan menjadi timpang lagi. Upaya yang serius untuk melindungi anak harus memastikan bahwa setiap lini dalam kebijakan publik dan setiap sistem yang ada di negara ini memang siap dan mampu melindungi anak. Upaya parsial dan emosional tak dapat dibenarkan sebab sumber daya yang terbatas harus digunakan secara optimal. Absennya perawatan psikososial pascatrauma merupakan kejahatan tersendiri dalam sistem terhadap korban. Dalam kerangka preventif, perlu mempertimbangkan rehabilitasi pada pelaku. UU Perlindungan Anak dirancang dengan

\footnotetext{
${ }^{26}$ Irwanto. Konsekuensi Perppu Nomor 1 Tahun 2016. Kompas, 3
} Juni 2016, h.6. semangat menjunjung perspektif anak sebagai korban. Artinya, ketika anak melakukan tindakan pidana, tindakannya juga dilakukan dalam posisi sebagai korban. Persoalannya adalah ketika anak juga dikenai pasalpasal yang lebih berat dari UU Perlindungan Anak. Jika ini yang terjadi, UU ini menjadi pisau lipat yang melukai pihak-pihak yang seharusnya dilindungi. Terbitnya Perppu tak memberi jawaban persoalan ini. Batalkan Perppu dan tugaskan pihak-pihak terkait untuk membuat kajian yang komprehensif. ${ }^{26}$ Perppu menurut Hargens ada baiknya bila bicara soal keberpihakan secara emosional pada korban. Sayangnya, yang dibutuhkan adalah keberpihakan moral yang mengharuskan adanya solusi adil untuk semua, yakni adil untuk korban dan pelaku. Perspektif humanis tak mutlak memandang pelaku sebagai penjahat, tetapi sekaligus manusia yang mempunyai hak untuk dilindungi oleh negara. Setiap pelaku 
memang harus diadili, tetapi tidak dengan cara yang tidak adil. ${ }^{27}$

Ketua Umum Pengurus Besar Ikatan Dokter Indonesia (PB IDI) Ilham Oetama Marisi meminta pada pemerintah untuk mempertimbangkan kembali Perppu yang mengatur hukuman tambahan kebiri kimiawi. Dokter agar tidak dijadikan sebagai eksekutor. IDI mendukung penerapan hukuman seberat-beratnya kepada pelaku kejahatan seksual. Akan tetapi, bukan dengan cara kebiri kimiawi karena bertentangan dengan sumpah dan kode etik kedokteran. PB IDI menolak apabila dokter ditugaskan untuk melaksanakan eksekusi suntik kebiri kimiawi. Efek samping kebiri sangat negatif. Berdasarkan Fatwa Majelis Kehormatan Etik Kedokteran (MKEK) Nomor 1 Tahun 2016 tanggal 8 Juni 2016 menegaskan bahwa profesi dokter bertujuan untuk memberikan kebaikan dengan cara menyembuhkan orang lain. Dalam prosesnya, dokter wajib menghormati otonomi pasien. Sesuai dengan

\footnotetext{
${ }^{27}$ Boni Hargens. Apologi Negara. Kompas, 13 Juni 2016, hlm.7.
}

sumpahnya, dokter tidak boleh berbuat semena-mena, apalagi menyakiti diri sendiri dan orang lain, meski keselamatan dokter tersebut sedang berada di bawah ancaman. Tindakan kebiri kimiawi dinilai bertentangan dengan semangat yang diemban oleh PB IDI karena bersifat menganiaya. Sumpah kedokteran bersifat universal, baik untuk dokter sipil, kepolisian, dan militer. Bila melanggar akan dikeluarkan dari profesi dokter dan organisasi profesinya. Solusi terbaik untuk menangani pelaku kekerasan seksual adalah terapi. Kebiri kimiawi hanya menurunkan hormon libido, tetapi sama sekali tidak berpengaruh pada pemikiran agresif, penguasaan impuls, ataupun keinginan untuk menyakiti orang lain. Dampak samping negatif dari kebiri kimiawi antara lain mengurangi kadar otot, meningkatkan lemak tubuh, dan mengurangi kemampuan kognitif. ${ }^{28}$ Menurut Wapres Jusuf Kalla, Jumat 10 Juni 2016, eksekusi kebiri dilakukan oleh dokter yang tak

\footnotetext{
${ }^{28}$ Kompas, 10 Juni 2016.
} 
tergantung dalam IDI, yakni dokter kepolisian. Anggota Komisi III DPR RI FPPP Arsul Sani Minggu 12 Juni 2016 meminta IDI tak langsung menolak untuk menjalankan hukuman kebiri kimiawi bagi pelaku kejahatan seksual terhadap anak. IDI perlu melihat dokter negara lain yang menerapkan hukuman kebiri juga memiliki kode etik dan tak menolak mengebiri. Persoalannya, tinggi mana antara melaksanakan perintah UU dengan kode etik kedokteran. Bila menolak, IDI dianggap sebagai bentuk obstruction of justice, yakni menghalangi penegakan hukum dan keadilan. Dalih IDI, dokter tak akan menggunakan pengetahuannya untuk hal yang bertentangan dengan perikemanusiaan, sekalipun diajak. Hal itu disebutkan dalam sumpah dokter. Dokter bertugas hanya untuk kepentingan kemanusiaan. Dalam peperangan pun, dokter harus menyelamatkan manusia, sekalipun itu musuh. ${ }^{29}$

Menurut Ketua Gugus Kerja Perempuan dalam Konstitusi Hukum Nasional Komnas Perempuan,
Khariroh Ali, ia menyangsikan kebiri memberi efek jera bagi pelaku sehingga ia lebih mendorong pembahasan RUU Penghapusan Kekerasan Seksual (PKS) ${ }^{30}$ Hingga pertengahan Oktober 2016, RUU PKS masuk dalam daftar prolegnas prioritas 2016. Muatan RUU PKS di antaranya perlindungan hukum yang komprehensif bagi para korban kekerasan seksual dan tata cara pencegahan atau pun penanganannya. RUU PKS memiliki 184 pasal yang berisi antara lain menjelaskan bentuk kekerasan seksual, cara pencegahan berupa pendidikan masyarakat mengenai kesehatan reproduksi, penanganan, pemulihan korban, pemidanaan, dan rehabilitasi pelaku. Wacana RUU Penghapusan Kekerasan Seksual menjadi UU. Dalam RUU tersebut, ada 9 jenis kekerasan seksual meliputi pelecehan seksual, pemaksaan kontrasepsi, pemaksaan aborsi, pemerkosaan, pemaksaan perkawinan, pemaksaan pelacuran, perbuatan seksual, dan penyiksaan seksual.

\footnotetext{
30 Tribun Jateng.Com, 13 Oktober 2016.
} 
Ada delapan jenis kekerasan seksual, yakni pemaksaan perkawinan, eksploitasi seksual, dan perbudakan seksual. Di samping itu, kekerasan seksual, di dalam hukum pidana masih dipandang dari sudut kesusilaan. Artinya, bila terjadi pelecehan, korban justru merupakan pihak yang pertama kali disalahkan dengan tuduhan telah bersikap tidak sesuai dengan norma kesusilaan. Menurut Ketua Komnas Perempuan Azriana Rambe Manalu, bentuk kekerasan seksual yang baru dikenal di dalam sistem hukum Indonesia adalah pemerkosaan dan pencabulan. ${ }^{31}$ RUU PKS merupakan inisiatif masyarakat kepada negara yang digawangi oleh Komnas Antikekerasan terhadap perempuan. Kinerjanya bekerja sama dengan LSM dan kaukus perempuan parlemen Indonesia. RUU PKS dianggap mendesak karena, pertama, catatan akhir tahun 2016 versi Komnas Perempuan, terjadi 321.752 kasus kekerasan terhadap perempuan yang dilaporkan pada Komnas Perempuan dan pengadilan agama.
Sebanyak 3.325 di antaranya berupa kekerasan seksual yang terbanyak (72 persen) adalah pemerkosaan, disusul pencabulan dan pelecehan seksual. Kedua, belum ada payung hukum terkait kekerasan seksual sehingga RUU PKS menjadi aturan khusus (lex specialis) dari KUHP. Ketiga, KUHP tidak memiliki cakupan yang luas mengenai berbagai jenis kekerasan seksual. Dalam KUHP hanya mencakup pemerkosaan dan pencabulan yang hanya di pasal 285 . Selebihnya, pasal 285-288 menggunakan istilah bersetubuh. Disebut persetubuhan bila alat kelamin lelaki melakukan penetrasi pada alat kelamin perempuan. Maknanya, bila kekerasan seksual dilakukan dengan anggota tubuh selain kelamin atau pun menggunakan benda, tidak dianggap pemerkosaan sehingga hukumannya tak seberat hukuman atas tindakan pemerkosaan. Keempat, RUU PKS meliputi kekerasan domestik (dalam rumah tangga) dan di luar rumah tangga. Selama ini, kekerasan domestik telah ada dalam UU Nomor

\footnotetext{
${ }^{31}$ Kompas, 11 Oktober 2016.
} 
23 Tahun 2004 tentang Kekerasan dalam Rumah Tangga (KDRT) yang tak menjangkau pada pelaku kekerasan di luar domestik, seperti kekerasan dalam pacaran. Selama ini, dinyatakan kekerasan seksual bila dilakukan di luar ikatan perkawinan sehingga kekerasan suami pada isteri atau sebaliknya tak dikategorikan tindak pidana. Kelima, pencegahan terjadinya kekerasan seksual akan diatur secara spesifik dalam RUU PKS. Seluruh unsur pendidikan, infratsruktur tata ruang, pelayanan publik, ekonomi, sosial, dan kelembagaan diharuskan memiliki perspektif pencegahan kekerasan seksual. RUU PKS akan menjadi prioritas program legislasi nasional (prolegnas) 2017, meski gagal masuk prolegnas 2016.

Muatan RUU PKS yang tak ada dalam KUHP dan KUHAP yakni mencakup berbagai jenis kekerasan seksual (dalam KUHP hanya menyangkut pemerkosaan dan pencabulan), kekarasan seksual oleh korporasi, pidana tambahan berupa ganti rugi pada korban, pidana pokok berupa rehabilitasi khusus kepada pelaku untuk mengubah pola pikir dan mencegah pelaku mengulang kejahatan, pidana tambahan berupa pencabutan hak asuh dan hak politik pelaku, pemulihan fisik, psikologis, status sosial, dan ekonomi korban; penyidik, jaksa penuntut, dan hakim harus berpengetahuan HAM dan jender dalam menangani kasus kekerasan seksual, korban wajib didampingi di setiap pemeriksaan antara lain oleh kuasa hukum, psikolog, orang kepercayaan korban, atau penerjemah bahasa isyarat/bahasa ibu/bahasa asing, alat bukti mencakup: keterangan dari korban, psikolog/psikiater, rekam medis/hasil forensik, rekaman pemeriksaan saat penyidikan, informasi yang diucapkan, dikirim, diterima atau disimpan secara elektronik, dengan alat optik, dsb., dokumen yang bisa dilihat, dibaca, atau didengar yang bisa dikeluarkan dengan/tanpa bantuan suatu sarana, pemeriksaan rekening bank.

Di sisi lain, diwacanakan pula RUU Pengasuhan Anak karena UU Nomor 35 Tahun 2014 tentang Perubahan atas UU Nomor 23 Tahun 2002 
tentang Perlindungan Anak dipandang perlu UU lain, UU serupa sedang diwacanakan, yakni UU Pengasuhan Anak. Dalihnya, UU Nomor 35 Tahun 2014 hanya ada beberapa pasal yang terkait dengan pengasuhan dan belum adanya pengasuhan anak dalam keluarga. Data Lembaga Perlindungan Anak (LPA) hampir setiap hari ada pengaduan yang berkaitan dengan pengasuhan anak ke LPA pusat dan daerah. Anak menghadapi posisi sulit tatkala orangtuanya bercerai, kondisi anak yatim/piatu, sehingga perlu aturan pihak mana yang wajib mengasuh. Belum lama berselang sejak Perppu dijadikan UU, pemerkosaan terhadap anak (usia 5 tahun) oleh 7 anak (usia 9-11 tahun) terjadi di rumah kosong di kampung padat hunian, yakni Prumpung, Kecamatan Jatinegara, Jakarta Timur. Peristiwa terjadi dua kali sehingga Kamis 20 Oktober 2016 dilaporkan oleh orangtua si korban pada polisi. ${ }^{32}$ Upaya di atas, terdapat upaya riil yang perlu dioptimalkan, yakni pusat pembelajaran keluarga (puspaga) yakni pola pengasuhan pada anak oleh keluarganya, sekolah, dan lingkungan sekitar, seperti penegak hukum, sebagaimana konvensi hak anak. Puspaga merupakan bagian dari program kabupaten/kota layak anak (KLA) yang memiliki 31 syarat. Puspaga dikelola oleh profesional di bidang psikologi dan tumbuh kembang anak, bukan oleh kader. Hingga akhir 2016 terdapat 18 kabupaten/kota penyelenggara KLA. Penulis 'menyadap' wacana prokontra ukuman kebiri dari para pemangku kuasa dan ahli yang ekspert di bidangnya, di antaranya diakses dari Rappler. com 22 Oktober 2015. Pendapat kontra muncul dari para ahli. Pertama, pada 21 Oktober 2016, Masruchah, anggota Komnas Perempuan, ia tidak setuju kebiri karena sebagian dari pelanggaran HAM. Bila efek jera yang dicari maka dapat dilakukan dengan memaksimalkan hukuman yang sudah berlaku saat ini. UU Nomor 23 Tahun 2002 tentang Perlindungan Anak, hukuman maksimal bagi pelaku kejahatan seksual terhadap

\footnotetext{
${ }^{32}$ Kompas, 21 Oktober 2016.
} 
anak di bawah umur adalah 15 tahun penjara selama 3-15 tahun dan denda sekitar Rp 60 juta s.d 300 juta. Kedua, dr. Boyke Dian Nugraha, pakar seksologi. Hukuman kebiri tidak efektif karena pelaku masih berpotensi melakukan kejahatan selama kondisi mentalnya tidak diobati. Yang sakit itu jiwanya dan kebiri tak akan menyelesaikan jiwanya. Cara yang tepat dengan memberikan pengobatan dan rehabilitasi bagi pelaku dan anak diberi pendidikan seks sehingga mampu melindungi diri. Ketiga, Seto Mulyadi, agar pemerintah mengkaji ulang berdasarkan aspek kesehatan dan psikologis. Secara psikologis, pelaku yang dikebiri akan bertindak lebih agresif dan menyasar ke kekerasan lainnya. Keempat, Imdadun Rakhmat komisioner Komnas HAM, hendaknya hukuman kepada pelaku bukan berupa balas dendam. Hukuman pada pelaku kriminal bertujuan memberi ganjaran setimpal dan pembinaan agar pelaku kembali menjadi manusia yang baik. Hukuman yang bersifat merendahkan martabat manusia tak memberi jaminan penyelesaian masalah, tetapi memuaskan dendam semata. Hukuman itu rawan menimbulkan dendam berkelanjutan bagi pelaku atau orang yang merasa dipermalukan. Solusinya adalah memaksimalkan hukuman kurungan di lembaga pemasyarakatan (LP). Sekjen Koalisi Perempuan Indonesia yang menangani pendampingan korban kekerasan seksual menyatakan, 68 LSM mengajukan surat permohonan audiensi kepada Presiden Jokowi bahwa mereka bersedia menyumbangkan pemikiran untuk solusi atas masalah kekerasan seksual pada anak. ${ }^{33}$

Naskah peraturan pengganti UU (Perppu) terkait kebiri (awalnya) berjudul Peraturan Pengganti Perundang-Undangan Perubahan kedua atas UU Nomor 23 Tahun 2003. Dalam drafnya menyatakan, hukuman kebiri berupa suntikan zat kimia guna menekan hasrat seksual pelaku kekerasan seksual terhadap anak. Hukuman baru bisa diberikan jika terpidana secara sukarela

\footnotetext{
${ }^{33}$ Kompas, 15 Januari 2016.
} 
mengajukan kesediaan disuntik sebagai bagian dari terapi bagi pelaku kejahatan seksual berulang. Pengajuan kesediaan disuntik kimia tersebut ketika pelaku dihukum kurungan di lembaga pemasyarakatan dan menjalani rehabilitasi mental dan sosial, terpidana yang merasa sukar mengurangi hasrat seksualnya boleh mengajukan permintaan suntik kimia dalam jangka waktu tertentu. Tatkala direhabilitasi, pelaku kejahatan tetap diadvokasi dan hukuman kebiri merupakan hukuman terakhir. Suntik kimia ini bagian dari upaya merehabilitasi pelaku yang sedang menjalani hukuman pidana kurungan. Deputi Perlindungan Anak Kementerian Pemberdayaan Perempuan dan Perlindungan Anak Pribudiarta Nur seusai pertemuan koordinasi Rencana Penyusunan Peraturan Perundangan Hukum Tambahan bagi Pelaku Kejahatan Seksual Anak di Jakarta, Selasa 10 November 2015 menyatakan, penambahan hukuman kepada pelaku kejahatan seksual terhadap anak hendaknya bersifat komprehensif, yaitu tidak sekedar menghukum, tetapi juga merehabilitasi. Bila hanya hukuman tidak menyelesaikan masalah. Pembinaan yang berkesinambungan dibutuhkan. Menteri Kesehatan Nila Moeloek menjelaskan bahwa penerapan hukuman kebiri, baik melalui suntik hormon untuk menekan libido maupun kastrasi testis, berisiko menimbulkan masalah kejiwaan lebih lanjut kepada pelaku. Hal ini juga tidak menjamin pelaku tak memiliki amarah dan agresi yang dilampiaskan dalam bentuk kekerasan lain, seperti fisik, psikis, dan verbal. Lebih baik mengutamakan tindakan pencegahan kekerasan. $^{34}$ Kementerian Pemberdayaan Perempuan dan Perlindungan Anak (PPPA) pada 19 Januari 2016 mengadakan rapat dengan Menkumham dan Jaksa Agung membahas final naskah Perppu. Pemerintah beralasan, penghukuman menambah efek jera bagi pelaku. Mengacu pada negara yang memberlakukan kebiri, seperti Australia, sembilan negara bagian Amerika Serikat, Perancis, dan

\footnotetext{
${ }^{34}$ Kompas, 11 November 2015.
} 
Swedia merupakan hukuman tambahan kepada pelaku yang sudah divonis hukuman kurungan. ${ }^{35}$

\section{Dinamika Politik Penerbitan Perppu}

Berdasarkan Keputusan Mahkamah Konstitusi (MK) Nomor 138/PUUVII/2009 bahwa menerbitkan Perppu membutuhkan tiga persyaratan, yakni adanya keadaan berupa kebutuhan mendesak untuk menyelesaikan masalah hukum secara cepat berdasarkan UU; UU yang dibutuhkan tersebut belum ada sehingga terjadi kekosongan hukum atau ada UU tetapi tak memadai; dan kekosongan hukum tersebut tak dapat diatasi dengan cara membuat UU secara prosedur biasa karena akan memerlukan waktu yang cukup lama sedangkan keadaan yang mendesak tersebut perlu kepastian untuk diselesaikan. Mahkamah berpendapat, tiga syarat tersebut merupakan syarat adanya kegentingan yang memaksa sebagaimana dimaksud dalam Pasal 22 (1) UUD 1945. Perppu melahirkan

\footnotetext{
${ }^{35}$ Kompas, 15 Januari 2016.
}

norma hukum dan sebagai norma hukum baru akan menimbulkan status hukum baru, dan hubungan hukum baru.

Rapat internal Komisi VIII DPR RI yang membidangi isu sosial pada Selasa, 19 Juli 2016 terbelah dalam menyikapi Perppu. Ada yang menginginkan substansi Perppu dimasukkan dalam materi RUU Penghapusan Kekerasan Seksual yang diusulkan DPR dan masuk dalam perubahan prolegnas prioritas 2016. Ada pula yang mengusulkan untuk segera disahkan menjadi UU agar tidak ada kekosongan hukum dan materi Perppu tak perlu digabungkan dalam RUU Penghapusan Kekerasan Seksual. Perppu oleh presiden untuk mengatasi kegentingan akibat maraknya kasus kekerasan terhadap anak. DPR akan meminta penjelasan sejumlah menteri, yakni Mensos, Menkumham, dan Menteri Pemberdayaan Perempuan dan Perlindungan Anak. ${ }^{36}$

Rapat Paripurna DPR dengan agenda pembicaraan tingkat II atas

\footnotetext{
${ }^{36}$ Kompas, 20 Juli 2016.
} 
pembahasan RUU tentang Penetapan Perppu Nomor 1 Tahun 2016 tentang Perlindungan Anak di Jakarta 23 Agustus 2016 diputuskan menunda pengesahan Perppu menjadi UU. Tiga fraksi belum memberikan sikap atas persetujuan Perppu menjadi UU, yakni Gerinda, Demokrat, dan PKS. Alasan penundaan, pertama, prosedur pembahasan Perppu dinilai tak sesuai dengan Pasal 22 ayat 2 UUD 1945 dan Pasal 52 UU Nomor 21 Tahun 2011 tentang Pembentukan Peraturan Perundang-Undangan. Kedua pasal menyebutkan, pemerintah mengajukan Perppu pada masa persidangan DPR berikutnya. Perppu baru dikeluarkan pada 25 Mei 2016, saat itu DPR melangsungkan masa sidang V 2015/2016, seharusnya Perppu baru diajukan dan dibahas pada masa sidang DPR I tahun 2016/2017 yang dimulai 16 Agustus. Kedua, masih ada enam isu dalam Perppu yang diperdebatkan, yakni (1) data kekerasan seksual terhadap anak, (2) peta terjadinya kekerasan dan upaya pemerintah menguranginya sebagai dasar keluarnya Perppu tak

\footnotetext{
${ }^{37}$ Kompas, 24 Agustus 2016.
}

jelas, (3) klausul penyakit menular di Perppu dibutuhkan pembuktian aspek medis sehingga ada bukti yang cukup, (4) mengacu pada penjelasan dari IDI, yaitu orang melakukan kejahatan seksual tidak semata-mata memiliki hasrat libido yang tinggi, tetapi juga faktor mental, sehingga kebiri bukan solusi efektif, (5) IDI juga menolak sebagai eksekutor hukuman kebiri karena kode etik kedokteran tidak memungkinkan dokter menjadi eksekutor, dan (6) Perppu juga belum mengatur teknis pidana tambahan berupa pemasangan alat pendeteksi elektronik. ${ }^{37}$ Menurut Maman Imanulhaq, anggota Komisi VIII DPR F-PKB, sebaiknya menunda pengesahan Perppu menjadi UU karena pemerintah belum bisa menjelaskan soal dana dan cara mengeksekusinya dan tak menyasar akar persoalan. ${ }^{38}$ DPR RI akhirnya mengesahkan Perppu Nomor 1 Tahun 2016 menjadi UU Nomor 17 Tahun 2016 tentang Penetapan Perppu Nomor 1 Tahun 2016 tentang Perubahan Kedua atas UU Nomor 23 Tahun 2012 tentang Perlindungan

\footnotetext{
${ }^{38}$ Kompas, 30 Agustus 2016.
} 
Anak menjadi UU pada Rabu 12

Oktober 2016, meskipun Fraksi PKS

DPR menyetujui disertai catatan dan

Fraksi Gerindra menolak. Pada 25

Mei 2016 Presiden Jokowi

menandatangani Perppu Nomor 1

Tahun 2016 menjadi UU Nomor 17

Tahun 2016 tentang Perppu

Pengganti UU Nomor 1 Tahun 2016

tentang Perubahan Kedua atas UU

Nomor 23 Tahun 2002 tentang

Perlindungan Anak menjadi UU. UU

ditandatangani Presiden Jokowi pada

tanggal 9 November 2016.

Hal yang tajam dalam muatan UU tersebut bahwa pelaku kekerasan seksual dapat diganjar hukuman kebiri, hukuman mati, dan dipasang chip elektronic. Di sisi lain, tak mengatur hak korban untuk mendapatkan keadilan dan pemulihan. Penolakan aspek lain dengan dalih bertentangan dengan UU Nomor 5 Tahun 1998 tentang Pengesahan Konvensi Menentang Penyiksaan dan Perlakuan atau Penghukuman Lain yang kejam, tak manusiawi, atau merendahkan martabat manusia. Di sisi lain, Komisi Perlindungan Anak mendukung Perppu menjadi UU karena membutuhkan hukuman yang mengerikan agar pelaku kekerasan seksual terhadap anak jera. Hal mendasar yang perlu dipahami sebagai masalah utama adalah belum terbentuknya sinergi dalam menjamin kehidupan yang aman dan nyaman bagi anak di tengah masyarakat. Perlu pula upaya rehabilitasi korban kekerasan. Jangan sampai ada anggapan bahwa urusan dengan korban selesai setelah penangkapan dan diadilinya pelaku. Padahal, korban trauma bahkan seumur hidupnya.

\section{Anak Korban Pemerkosaan Pasca- pengesahan Perppu menjadi UU}

Deretan kasus pelanggaran terhadap anak tahun 2016 berdasarkan data Komisi Perlindungan Anak Indonesia (KPAI) menerima laporan 3.581 pengaduan. Kasus tersebut yang berhadapan dengan hukum ada 1.002 kasus, terkait keluarga dan pengasuhan alternatif 702 kasus, kejahatan anak berbasis siber 414 kasus seperti bullying, prostitusi online, penculikan, penipuan, hate speech, dan terorisme, serta 
pelanggaran dalam pendidikan 328 kasus. Kasus tersebut tidak disebabkan oleh faktor tunggal. Dari sisi penegakan hukum, vonis bagi pelaku dewasa yang melakukan kejahatan seksual terhadap anak masih jauh dari rasa keadilan bagi korban. Di 34 Pengadilan Negeri provinsi dengan sampel 112 kasus, pelaku dewasa rata-rata divonis 5-10 tahun (35 persen) dan 44 persen divonis 10-15 tahun. Upaya KPAI, pertama, advokasi kepada penyelenggara negara akan pentingnya kebijakan yang berperspektif anak di berbagai bidang dan sektor pembangunan, baik pusat maupun daerah. Kedua, melakukan advokasi agar paradigma perencanaan, penganggaran, pelaksanaan, dan evaluasi pembangunan berbasis pada perspektif perlindungan anak. Ketiga, mengadvokasi penguatan kelembagaan perlindungan anak yang didukung oleh SDM, anggaran, dan struktur birokrasi yang responsif terhadap perlindungan anak. ${ }^{39}$

\footnotetext{
${ }^{39}$ Asrorun Niam Sholeh. Wajah Perlindungan Anak 2016. Kompas, Jumat 13 Januari 2017, h..7.
}

Penulis mengakses informasi pemerkosaan terhadap anak pascapengesahan Perppu menjadi UU, di antaranya, Pertama, yang dialami SR (15 tahun) siswi kelas X SMA. Ia menjadi korban pemerkosaan dan dianiaya dengan disundut rokok oleh delapan pelaku di ruang kelas SMPN di Pematang Siantar, Sumatera Utara, Minggu 25 Desember 2016 dini hari hingga trauma. Para pelaku yakni RIS (20 tahun), JRS (18 tahun), dan AJP sudah ditangkap Polres Pematang Siantar, RIS dan AJP ditahan, sedangkan JRS dijadikan tahanan rumah karena masih usia anak. Awalnya, pelaku mengajak SR berkeliling dengan sepeda motor hingga dibawa ke lokasi pemerkosaan dan korban diancam bila memberitahukan pada pihak lain. Pelaku mengantarkan korban pukul 06.00 ke rumah orangtuanya. Setiba di rumah, korban menceritakan pada keluarganya atas kejadian semalam. Keluarga melaporkan kejadian tersebut pada Polres Pematang 
Siantar. ${ }^{40}$ Kedua, sodomi diderita A (6 tahun) siswi MIN 2 Kota Padangsidimpuan, Sumut oleh dua kakak kelasnya, RC (12 tahun) warga Kelurahan Palopat dan RY (12 tahun) warga Desa Limbong, Kecamatan Padangsidimpuan Tenggara, Kota Padangsidimpuan. Korban dipaksa masuk kamar mandi madrasah dan dipaksa pelaku. Hal ini terungkap tatkala korban dimandikan orangtuanya di rumah meminta agar tidak mengoleskan sabun ke duburnya karena anusnya sakit akibat dimasuki kayu oleh pelaku. Sang ibu membawanya ke rumah sakit dan melaporkan pada Polres Padangsidimpuan Rabu 11 Januari 2017 (Sindonews.Com, Jumat 13 Januari 2017). Ketiga, anak perempuan berinisial KM (6 tahun) tewas dibunuh setelah diperkosa oleh tiga tersangka berinisial DO, NA, dan LE di sebuah kali di ujung landasan Bandara Domine Eduard Osok, Kelurahan Klasabi, Kota Sorong, Papua Barat, Selasa 10 Januari 2017. Tersangka, ketiganya ditahan di Mapolres Sorong. ${ }^{41}$ Keempat, dua

\footnotetext{
${ }^{40}$ Kompas, Kamis 29 Desember 2016.
}

petani, Has (40 tahun) dan $\mathrm{Uj}$ (44 tahun) warga Kelurahan Tagaraja, Kecamatan Kateman, Kabupaten Indragiri Hilir memerkosa $\mathrm{Tu}$ (16 tahun) dan Te (17 tahun) pada Selasa 17 Januari 2017. Sabtu 21 Januari 2017 orangtua korban melaporkan pada Polsek Kateman. Awalnya, ketika dua korban Selasa 17 Januari 2017 pukul 21.00 perjalanan pulang mengendarai sepeda motor. Saat itu hujan sehingga jalan licin. Lalu muncullah kedua pelaku. Kelima, kejadian serupa dialami gadis pelayan kafe berinisial $\mathrm{R}$ (18 tahun) warga Nagari Sungai Beringin, Kecamatan Payakumbuh, Kabupaten Limapuluh Kota, Sumatera Barat menjadi korban pemerkosaan oleh 7 orang (diduga anggota TNI). Kejadian terjadi pada Jumat 20 Januari 2017 malam di kafe CF di Kelurahan Talang, Kelurahan Payakumbuh Barat, Payakumbuh. Korban dicekoki minuman keras hingga pingsan hingga dirawat di rumah sakit. Warga mendatangi kafe

\footnotetext{
${ }^{41}$ Kompas, Jumat 13 Januari 2017.
} 
CF sekitar pukul 22.15 dan membakarnya. ${ }^{42}$

Keenam, kekerasan seksual terhadap anak yang dilakukan ayah kandung dan ayah tiri terjadi di Pondok Aren, Tangerang Selatan (Tangsel), Banten. Polres Tangsel mengungkap pemerkosaan dan pencabulan yang dilakukan oleh JS (31 tahun) ayah tiri PA (10 tahun) dan ROR (7 tahun). PA diperkosa dan ROR dicabuli sejak Februari 2017 tatkala sang ibu kedua gadis itu berdagang sayuran. Begitu pula Nisin (44 tahun) duda warga Kelurahan Ciater, Kecamatan Serpong, Tangsel menghamili anak kandungnya IN (17 tahun) sejak dua tahun lalu dan melahirkan 2 anak hasil perkosaan sang ayah kandung. Para pelaku mengancam korban agar tak melaporkan perbuatannya pada pihak mana pun. Terbongkarnya kasus karena korban melahirkan meski status gadis sehingga diketahui para tetangganya. Anak yang dilahirkan diadopsi pihak lain. ${ }^{43}$ Ketujuh, AL 8 tahun siswi kelas 4 SDN Gondosari, Kecamatan Gebog, Kudus, Jateng warga Nalumsari
Kabupaten Jepara (tetangga Kudus) dibuli atau korban perundungan di kelas pada jam sekolah (pukul 08 - 09 Wib) oleh teman sekelasnya Rabu 19 Juli 2017. Kekerasan itu dalam bentuk dipukul, ditindih dengan kursi, kemaluannya ditusuk penggaris besi hingga lecet. Pemicunya, korban tidak mau menuruti keinginan pelaku sebagai ketua geng bernama Geng Fisa berinisial F. Kelompok geng terdiri sembilan anak. Saat kejadian di kelas, guru sedang rapat di kantor sekolahnya. Kasus ini masuk meja Polres Kudus Sabtu 29 Juli 2017 dan telah divisum di puskesmas dan Rumah Sakit Lukmonohadi Kudus. Selanjutnya, kasus ditangani Dinas Pendidikan Pemuda dan Olahraga (Disdikpora) Kudus. Sejak kejadian itu, korban dipindah ke sekolah lain. Korban mendapat pendampingan dari Jaringan Perlindungan Perempuan dan Anak (JPPA) Kudus dengan memvisum korban, assesment pada korban dan pelaku, mengedukasi pada keluarga dan pelaku. Hingga ditulisnya naskah ini, kasus tersebut

\footnotetext{
${ }^{43}$ Kompas, Sabtu 22 Juli 2017.
} 
belum diperoleh penulis hasil akhir penegakan hukumnya.

Selain itu, Budiansyah bin Anda (29 tahun) terdakwa perkara pemerkosaan dan pembunuhan terhadap LN (2 tahun) divonis mati oleh Ketua Majelis Hakim PN Cibinong, Jawa Barat, Indah Watukumala Wulan, didampingi hakim anggota RA Rizkiyati dan Eko Julianto, Kamis 19 Januari 2017. Putusan itu lebih berat daripada tuntutan jaksa yang menuntut hukuman seumur hidup. Terdakwa membunuh berencana dan secara sadis di luar perikemanusiaan, terdakwa dinilai tak menyesali membunuh anak satu-satunya di rumahnya Kampung Pabuaran Bogor 8 Mei 2016. Terdakwa secara sah dan meyakinkan melanggar Pasal 340 KUHP dan Pasal 81 ayat $1 \mathrm{UU}$ Nomor 35 Tahun 2014 tentang Perlindungan Anak.

\section{Hakim Pengadilan Negeri}

Sangatta, Kalimantan Timur menerapkan pemberatan hukuman kejahatan seksual pada anak pada pelaku Jurjani alias Ijur. Jurjani melakukan tindak pidana pada
Agustus 2016. Jaksa mengenakan Pasal 81 ayat 1 dan 5 jo Pasal 76 huruf D Perppu Nomor 1 Tahun 2016. Dakwaan alternatif menggunakan Pasal 340 KUHP tentang Pembunuhan Berencana subsider Pasal 338 KUHP dengan tuntutan seumur hidup. Hakim memutuskan pembunuhan berencana dengan putusan hukuman mati.

\section{Urgensi bila Ada Fatwa MUI tentang Kebiri}

Ketua Komisi Fatwa MUI Hasanuddin AF Selasa 17 Mei 2016 menilai, hukuman berat layak diberikan kepada pelaku kejahatan seksual terhadap anak. MUI pun mendukung pemerintah untuk mengeluarkan hukuman kebiri karena sudah meresahkan. Dalih lain, dalam pandangan Islam, hukuman kebiri masuk dalam hukuman ta'zir atau tambahan yang boleh dikeluarkan dan diserahkan kepada kebijakan pemerintah, terlebih belum adanya UU yang mengatur mengenai hukuman bagi pelaku kejahatan seksual. Hasanuddin menambahkan, pemerintah perlu mengkaji agar hukuman kebiri dapat dilaksanakan 
dengan baik. ${ }^{44}$ Akan tetapi, Ketua Komisi Fatwa MUI Kabupaten Lebak, Banten tidak setuju adanya Perppu Nomor 1 Tahun 2016 karena suntik kebiri dengan obat antiandrogen bagi pelaku kejahatan seksual tidak tepat karena tidak bisa memutus mata rantai pelaku kejahatan seksual pada anak. Kebutuhan biologis merupakan kepentingan dasar manusia dan kebiri merusak salah satu organ tubuh yang berakibat tak berfungsinya organ. MUI Lebak lebih setuju penerapan hukuman berat di atas 20 tahun atau hukuman seumur hidup atau hukuman mati. ${ }^{45}$ Hingga ditulisnya naskah ini, MUI belum menerbitkan fatwa tentang hukuman kebiri. Padahal jauh sebelum ada perppu kebiri, Ketum MUI K.H Ma'ruf Amin Kamis 22 Oktober 2015 menyarankan agar pemerintah meminta fatwa MUI sebelum memberlakukan hukuman kebiri untuk menghindari permasalahan regulasi antara hukum Islam dengan ketentuan hukum pidana. Harapan Amin, seharusnya

\footnotetext{
${ }^{44}$ Republika.co.id Selasa 17 Mei 2016.
}

${ }^{45}$ Republika.co.id Sabtu 11 Juni 2016. minta fatwa dulu dari MUI, bila MUI mengeluarkan keputusan yang berbeda dengan pemerintah tidak menjadi kontroversi. Belum adanya aturan yang membolehkan hukuman kebiri, perlu pembahasan lebih detail, apakah kebiri dibenarkan dari sudut padang Islam. MUI siap melakukan kajian bila pemerintah meminta pendapat perihal hukuman kebiri. ${ }^{46}$

Tidak memintanya fatwa pada MUI oleh pemeritah dapat dimaknai tidak mempertimbangkannya kajian aspek hukum Islam di negara yang mayoritas wargaya muslim. Hal ini berdampak tidak optimalnya kinerja UU yang semula Perppu. Dengan kasus ini, meski meminta fatwa MUI bagi pemerintah bukanlah keharusan, tetapi setidak-tidaknya dengan fatwa MUI tentang kebiri menjadi pengokoh bahwa kebiri memiliki dasar hukum (Islam) atau tidak memiliki dasar hukum dalam Islam. Hal yang perlu dipahami adanya kata bijak: ad-dharuratu tubihu almahdhurat (keadaan yang mendesak dapat memperbolehkan hukuman

\footnotetext{
${ }^{46}$ Kompas.com, Kamis 22 Oktober 2015.
} 
yang sebenarnya terlarang). Akan tetapi kata bijak ini belum bisa diterapkan dengan pemberlakuan kebiri perspektif hukum Islam karena MUI belum dimintai fatwa. Hal lain yang perlu dipertimbangkan untuk diutamakan pemerintah selain diterbitkannya Perppu Nomor 1 Tahun 2016 tentang Kebiri adalah mengevaluasi pelaksanaan pendidikan kesehatan reproduksi.

\section{Pentingnya Pendidikan Kesehatan}

\section{Reproduksi dan Seksual}

Pendidikan kesehatan reproduksi dan seksual untuk mengenal tubuh dalam konstruksi jender, sosial, fisik, psikis, dan spiritual dan memahami dampaknya merupakan hak masyarakat. Dalam aspek hukum, terdapat PP Nomor 61 Tahun 2014 tentang Pengadaan Pendidikan Kesehatan Seksual dan Reproduksi yang perlu dijadikan pijakan pelaksanaan pendidikan reproduksi. Menurut Agustina, pendidikan seksualitas bukan pendidikan yang mengajarkan cara berhubungan seks, karena seksualitas berbeda dengan

\footnotetext{
${ }^{47}$ Nurul Agustina. Pendidikan Seksualitas. Kompas, 26 Mei 2016, hlm.6.
}

seks yang secara cepat diartikan sebagai kelamin atau perkelaminan. Pendidikan seksualitas pada prinsipnya bertujuan agar seseorang mampu menghargai diri sendiri dan orang lain dengan mengenal tak hanya tubuhnya dan proses reproduksinya, juga emosi dan mengelolanya. Tak sebatas memahami fisik, tetapi memanfaatkan segenap fakultas intelektual dan spiritual yang ada di balik wujud fisik dan sosial. Tidak hanya menghormati kedaulatan tubuh yang sempurna anugerah Tuhan juga kedaulatan tubuh orang lain. $^{47}$ Menurut Badan Kesehatan PBB (WHO) seksualitas didefinisikan sebagai istilah komposit yang mengacu pada totalitas kedirian, menunjukkan karakter manusia, seksualitas berkaitan dengan variabel biologis, psikologis, sosiologis, dan spiritual dari kehidupan yang memengaruhi perkembangan kepribadian dan hubungan interpersonal. Termasuk pula persepsi diri, harga diri, sejarah 
pribadi, kepribadian, konsep cinta dan keintiman, citra tubuh, dsb. Selain pendidikan kesehatan reproduksi, perlu pula melaksanakan keadilan restoratif pada anak Indonesia.

\section{Keadilan Restoratif pada Anak}

Diversi atau pengalihan pemberian hukuman penjara ke pembinaan bagi anak yang berhadapan dengan hukum wajib dilakukan sebagai wujud pendekatan keadilan restoratif. Tujuannya, mendidik dan memulihkan pelaku dan korban yang masih anak-anak, bukan balas dendam. Dalam UU Nomor 11 Tahun 2012 tentang Sistem Peradilan Pidana Anak yang memperlakukan anak sebagai aset bangsa. Data Kemenkumham hingga Maret 2015 terdapat 10.907 anak berhadapan dengan hukum, 3.429 anak masuk dalam proses diversi. Syarat diversi bagi anak adalah vonis di bawah 7 tahun penjara dan bukan pengulangan tindakan pidana ataupun prosedur diversi lainnya. Bila anak divonis di atas 7 tahun penjara, anak akan dikenai sanksi pidana yang dikurangi setengah dari waktu vonis sesuai

\footnotetext{
${ }^{48}$ Kompas, 29 April 2015.
}

dengan UU Nomor 35 Tahun 2014 tentang Perlindungan Anak. Proses diversi melibatkan pelaku, korban, keluarga kedua belah pihak, tokoh agama, tokoh masyarakat, dan aparat penegak hukum selaku fasilitator. ${ }^{48}$ Keterlibatan elemen sosial tersebut perlu dijembatani oleh negara agar benar-benar terwujud kiprahnya sebagai pertanggungajawaban sosial.

\section{Kesimpulan}

DPR mengesahkan Perppu Nomor 1 Tahun 2016 menjadi UU Nomor 17 Tahun 2016. Pemicu terbitnya Perppu kebiri diawali keprihatinan pemerintah dan organisasi pegiat sosial di bidang perlindungan anak atas meningkatnya jumlah/kuantitas dan kualitas tindak kriminal dan pemerkosaan yang diderita anak. Akan tetapi, model hukuman kebiri bagi pelaku mendapat respon negatif dari pegiat hak asasi manusia dan ahli medis karena ragam persoalan. Hal yang menjadi pertanyaan, terbitnya UU Nomor 17 Tahun 2016 melalui fase yang melelahkan, apakah dimanfaatkan oleh hakim dalam 
memvonis pelaku? Hingga ditulisnya naskah ini, penulis belum mendapatkan vonis hakim dalam bentuk kebiri. Dalam aspek lain, sebagai bahan perhatian pada pemerintah pada masa mendatang, idealnya meminta fatwa MUI sebelum membuat Perppu/UU agar publik muslim mendapatkan dasar hukum yang lebih kokoh. Hal yang utama untuk mendapat perhatian adalah perlunya pelaksanaan pendidikan kesehatan reproduksi dan seksual dan terwujudnya keadilan restoratif pada anak. 


\section{Daftar Pustaka}

Agustina, Nurul. Pendidikan Seksualitas. Kompas, 26 Mei 2016.

Faturochman. Pengantar Psikologi Sosial, Yogyakarta, Pustaka, 2006.

Irwanto. Konsekuensi Perppu Nomor 1 Tahun 2016. Kompas, 3 Juni 2016.

Irawaty, Diah. Sistem Pengawasan Terpadu Kekerasan Seksual. Kompas, 7 Juni 2016.

Harmadi, Sonny Harry B. SDG dan Makna Pembangunan. Kompas, Kamis 14 April 2016.

Hargens, Boni. Apologi Negara. Kompas, 13 Juni 2016.

Mohamad, Kartono. Pemerkosa Dikebiri. Kompas, 18 Mei 2016.

Pangkahila, Wimpie. Kebiri Kimia bagi Penjahat Seksual. Kompas, 13 Mei 2016.

Sa'abah, Marzuki Umar. Perilaku Seks Menyimpang dan Seksualitas Kontemporer, Yogyakarta, UII Press, 2001.

Suyanto, Bagong. Ancaman Kebiri bagi Pemerkosa Anak. Kompas, 3 November 2015.

Susanto. Presiden Ramah Anak. Kompas, 31 Mei 2016.

Sholeh, Asrorun Niam. Wajah Perlindungan Anak 2016. Kompas, Jumat 13 Januari 2017.

Wahid, Abdul dan Muhammad Irfan. Perlindungan terhadap Korban Kekerasan Seksual, Bandung, Refika Aditama, 2001.

Wahyudi, M. Zaid. Efektivitas Kebiri Masih Dipersoalkan. Kompas, 23 Oktober 2015.

Zaidan, M. Ali. Hukuman yang Merendahkan. Kompas, 31 Mei 2016. 